\title{
LGBT rights and inclusion in Small Island Developing States (SIDS)
}

Iffat Idris

University of Birmingham

25 February 2021

\section{Question}

What is the situation with regard to lesbian, gay, bisexual and transgender (LGBT) people in Small Island Developing States (SIDS)? - focus on legislation and enforcement of this.

What approaches have been effective in promoting LGBT rights and inclusion? What has not worked?

\section{Contents}

1. Summary

2. Situation in law of LGBT people in SIDS

3. Evidence from approaches/programmes to promote LGBT rights

4. Recommendations

5. References

The K4D helpdesk service provides brief summaries of current research, evidence, and lessons learned. Helpdesk reports are not rigorous or systematic reviews; they are intended to provide an introduction to the most important evidence related to a research question. They draw on a rapid deskbased review of published literature and consultation with subject specialists. other Government departments, but the views and opinions expressed do not necessarily reflect those of FCDO, the UK Government, K4D or any other contributing organisation. For further information, please contact helpdesk@k4d.info. 


\section{Summary}

Lesbian, gender, bisexual and transgender (LGBT) people in many small island developing states (SIDS) ${ }^{1}$ face numerous challenges, including with regard to rights under the law. In a large proportion of these countries, consensual same-sex sexual conduct has not been decriminalized, and none allow other rights such as for same-sex marriage or adoption. While laws criminalizing same-sex sexual conduct are rarely enforced, they create an environment which fosters discrimination and violence towards LGBT people. Overall, those in Caribbean SIDS fare worst. Approaches to promote LGBT rights through development programming include: support for legal reform; research on LGBT issues to inform policy-making; community mobilization and networking; capacity-building of LGBT groups; sensitisation of stakeholder groups such as parliamentarians; using HIV/AIDS programming to promote LGBT support; and mainstreaming LGBT into development cooperation. Given the sensitivities around LGBT issues (and perceived 'foreign interference') it is important to give local actors the lead in LGBT advocacy, and to frame global LGBT rights in terms that have local relevance.

This review looks at the extent to which LGBT rights are provided for under law in a range of SIDS, and the record on implementation/enforcement, as well as approaches to promote LGBT rights and inclusion. SIDS covered are those in the Caribbean, Pacific, and Atlantic-Indian Ocean-South China Sea (AIS) regions. The review draws on a mixture of grey literature (largely from international development agencies/NGOs), academic literature and media reports. While information on the legal situation of LGBT people in SIDS was readily available, there was far less evidence on approaches/programmes to promote LGBT rights/inclusion in these countries. However, the review did find a number of reports with recommendations for international development cooperation generally on LGBT issues. Gender was mentioned in the literature largely in the context of transgender people, while nothing was found on people with disabilities.

Note on terminology: the term lesbian, gay, bisexual and transgender (LGBT) is used in this review. Expanded terms commonly used in the literature are LGBTI (including intersex people) and LGBTIQ (including queer people); another common term is sexual orientation and gender identity (and expression) or SOGI/SOGIE. Where the literature cited uses these alternative terms, they are kept in this review.

Key findings of the review are as follows:

Importance of LGBT rights - Denial of LGBT rights and discrimination against LGBT people is found to varying extents in all parts of the world. It is important that LGBT people have protection in law, in particular the right to have same-sex sexual relations; protection from discrimination on the grounds of sexual orientation; and the right to gender identity/expression. Such rights are also provided for under international human rights conventions such as the Universal Declaration of Human Rights, while the Sustainable Development Goals are based on the principle of 'leave no one behind'.

1 There are 38 small island developing states (SIDS) which are UN members. These are divided geographically into three groups: i) Caribbean - 16 SIDS; ii) Pacific - 12 SIDS; and iii) Atlantic, Indian Ocean and South China Sea (AIS) - 9 SIDS. The same groupings are used in this review. There are also an additional 20 SIDS that are non-UN members/associate members of regional commissions, e.g. Guadeloupe, Puerto Rico, and Turks and Caicos Islands. This review does not look at those. 
Caribbean SIDS - LGBT people in the Caribbean face widespread discrimination and maltreatment. Many Caribbean countries criminalize same-sex sexual activities with punishments ranging from two years' to life imprisonment. None permit same-sex civil unions/marriage and adoption by same-sex couples, and only Cuba allows LGBT people to serve openly in the military and legal change of gender identity. While laws criminalizing homosexual sex are rarely enforced, they legitimize discrimination and hostility towards LGBT people; they also contribute to a lack of trust in the police by LGBT people. Some progress has been made in recent years on decriminalization.

Pacific SIDS - as in the Caribbean, LGBT people in Pacific SIDS face challenges. Only Fiji, Nauru and Vanuatu have decriminalized same-sex sexual conduct; in the rest, the law stipulates punishments of up to 5-14 years' imprisonment. None allow same-sex civil unions/marriage, adoption by same-sex couples, or LGBT people to openly serve in the military. Only Fiji has a comprehensive anti-discrimination law, though a number of Pacific SIDS have provisions prohibiting discrimination on the basis of sexual orientation and gender identity (SOGI) in employment. Despite a culture of 'third gender' in many SIDS, e.g. Samoa, none have laws on gender recognition. In SIDS criminalizing same-sex sexual conduct, no prosecutions are reported, but LGBT people are also targeted using other laws, e.g. relating to public order and indecency.

Atlantic-Indian Ocean-South China Sea (AIC) SIDS - Many countries in this group have decriminalized same-sex sexual conduct, but those that haven't include Singapore. Like the Caribbean and Pacific SIDS, these countries do not recognize same-sex civil unions/marriages, nor allow adoption by same-sex couples. Laws criminalizing same-sex sexual conduct are not enforced (unless in the context of sexual assault), but their existence intimidates LGBT people and prevents them reporting abuse or violence. Moreover, in Singapore, the government restricts LGBT rights in other ways, e.g. banning positive depictions of LGBT people on television/radio.

International development cooperation to promote LGBT rights - approaches used by international actors/development agencies to promote LGBT rights include: advocacy, HIV/AIDS and SRHC programmes, mainstreaming LGBT into development programmes, engagement with civil society/LGBT groups, and research to provide an evidence base for policy-making. All such programming can be challenging because of, for example, partner country sensitivities about LGBT issues, the fact that these affect only a minority of the population, and that social acceptance of LGBT is a relatively recent phenomenon even in Western countries.

Need to support LGBT rights in development cooperation and challenges - Promoting LGBT rights should be a policy priority in development cooperation for ethical (all people should enjoy human rights), economic (exclusion of LGBT people impedes economic development) and social (LGBT rights are strongly correlated with gender equality) reasons. However, there are significant challenges: LGBT issues are often controversial in developing partner countries, they affect only a minority of the population, and even in donor countries there can be intolerance of LGBT people/social acceptance can be a recent phenomenon.

Approaches to promote LGBT rights and inclusion through development assistance - include: advocacy, programmes to address HIV/AIDS and sexual and reproductive health care, mainstreaming LGBT issues in development programmes, engagement with civil society/LGBT groups to build their capacity, and research on LGBT issues to enable evidence-based support. It 
is also important to make LGBT people visible in national statistics and to enforce antidiscrimination and equality legislation.

Findings on efforts to promote LGBT rights in SIDS are as follows:

Advocacy through regional bodies can be more effective in the Caribbean - Global scale advocacy on LGBT rights can be ineffective because global bodies have limited buy-in from developing countries. Meanwhile, international direct advocacy to promote LGBT rights in the Caribbean can be rejected as 'cultural imperialism' (foreign norms) and can compromise efforts of local LGBT activists. A more effective approach could be to use regional bodies because: with regional similarities (ethnicity, culture, religious beliefs) and as smaller bodies, it is easier to agree on collective actions; there are also more equitable power dynamics than in larger/global groupings; and they allow greater space for LGBT people themselves to play a role.

Addressing research gaps through programmes in the Asia-Pacific and Caribbean - 'Being LGBTI in Asia and the Pacific' is a regional programme which seeks to fill the large research gaps on the human rights violations faced by LGBT people, with the aim of equipping duty bearers with the strategic information needed to address these. As well as individual country reports, it has produced reports on specific issues, e.g. employment, and manuals on promoting LGBT inclusion for stakeholders, e.g. parliamentarians. The subsequent programme of the same name in the Caribbean focuses on research and knowledge dissemination, as well as capacity building of civil society organizations.

United Nations Development Programme (UNDP) engagement in the Pacific - UNDP is working across the Pacific SIDS to promote LGBT rights using a range of approaches: sensitising parliamentarians; HIV/AIDS programming with key population groups including men who have sex with men (MSM) and transgender people; support for legislative reform (part of the Being LGBTI in Asia and the Pacific programme); and promoting safe homosexual sex through access to health services for marginalized groups.

Successful approaches in the Asia-Pacific region - A study (UNDP, 2015) attributes progress on advancing inclusion of LGBTI people in Asia and the Pacific to three factors: i) use of the response to HIV as an entry point to advocate for LGBTI rights, leading to policies that address LGBTI issues, mobilization and networking; ii) rise in LGBTI visibility in general in the region, assisted by the growth of social media, contributing to a more supportive environment for LGBTI people; iii) landmark developments in law and policy reform, e.g. decriminalization of homosexual conduct, creating more positive social environments for LGBTI people.

As well as in relation to LGBT rights' promotion in SIDS, the literature makes 'generic' recommendations for international development actors, key among which are:

- Support LGBT rights as fundamental human rights, and raise these in dialogues with partner countries.

- Frame LGBT rights in terms that are relevant to local discourse, and connect with traditional and religious leaders to foster change agents.

- Consult with local LGBT groups in countries of operation and let local actors have the lead voice in advocacy, with international partners providing capacity building/other support.

- Sensitise staff and delivery partners to ensure inclusion of LGBT groups, e.g. making LGBT a diversity criterion in recruitment - 'practise what you preach'. 
- Since civil society organizations (CSOs) working on such issues can struggle with funding, donors should review and adapt their sustainability criteria to enable such groups to continue their work.

- Visibility on LGBT issues can lead to backlash, so donors should be ready with safeguards (e.g. easy asylum procedures, funding for travel) to protect local activists.

- Ensure that the full range of LGBTI groups - especially lesbians, transgender and intersex people - are addressed in development programming.

- Support necessary research about LGBT issues and learning.

\section{Situation in law of LGBT people in SIDS}

\section{Context}

\section{Importance of LGBT rights}

Denial of LGBT rights and discrimination against LGBT people is found to varying extents in all parts of the world, but can be especially strong in developing countries with deeply religious, conservative societies - including many small island developing states (SIDS). According to the UN Office of the High Commissioner for Human Rights (OHCHR):2

Deeply-embedded homophobic and transphobic attitudes, often combined with a lack of adequate legal protection against discrimination on grounds of sexual orientation and gender identity, expose many LGBT people of all ages and in all regions of the world to egregious violations of their human rights. They are discriminated against in the labour market, in schools and in hospitals, mistreated and disowned by their own families. They are singled out for physical attack - beaten, sexually assaulted, tortured and killed.

This report does not look at all the drivers of discrimination against LGBT people, but rather focuses on the rights in law of LGBT people in SIDS, specifically: the right to have same-sex sexual relations; recognition of same-sex (civil) unions; recognition of same-sex marriage; adoption by same-sex couples; right of LGBT people to serve openly in the military; protection from discrimination on the grounds of sexual orientation; and the right to gender identity/expression (including the right to legally change gender). Provision of all these rights in legislation is essential. According to Tea Braun, Director of Human Dignity Trust ${ }^{3}$ :

Laws that criminalise lesbian, gay, bisexual and transgender people put them beyond the protection of the law, fostering a climate of fear and violence. Blackmail, extortion, and physical and sexual violence is commonplace.

\section{International commitments}

As well as national legislation, many SIDS countries have signed up to international human rights covenants which include protection of LGBT rights. Key international commitments in this regard include the Universal Declaration of Human Rights which states (APF \& UNDP, 2016: 89):

\footnotetext{
2 https://www.ohchr.org/en/issues/discrimination/pages/lgbt.aspx

${ }^{3}$ https://www.humandignitytrust.org/lgbt-the-law/
} 
'Everyone is entitled to all the rights and freedoms set forth in this Declaration, without distinction of any kind, such as race, colour, sex, language, religion, political or other opinion, national or social origin, property, birth or other status'. This is echoed in the International Covenant on Civil and Political Rights (ICCPR) (APF \& UNDP, 2016: 90):

All persons are equal before the law and are entitled without any discrimination to the equal protection of the law. In this respect, the law shall prohibit any discrimination and guarantee to all persons equal and effective protection against discrimination on any ground such as race, colour, sex, language, religion, political or other opinion, national or social origin, property, birth or other status.

The Sustainable Development Goals (SDGs), unanimously agreed by UN member countries in 2015, are based on the principle 'leave no one behind' (UNDP, 2017: 15). Especially relevant for LGBT inclusion are: SDG1 - end poverty in all its forms everywhere; SDG 3 - ensure healthy lives and promote well-being for all; SDG 4 - ensure inclusive and equitable education and lifelong learning opportunities for all; SDG 5 - achieve gender equality and empower all women and girls; SDG 10 - reduce inequality within and among countries; SDG 16 - promote peaceful and inclusive societies... provide access to justice for all and build...inclusive institutions at all levels (Stonewall International, n.d.).

In 2006 the Principles on the Application of International Human Rights Law in relation to Sexual Orientation and Gender Identity (also known as the Yogyakarta Principles) were agreed. These 'are the most authoritative statement of what international human rights law obliges States to do and not do in promoting and protecting the rights of persons of diverse sexual orientations and gender identities' (APF \& UNDP, 2016: 131). Simply put, they are a set of principles that apply international human rights law standards to issues that affect LGBTI people (UNDP, 2017: 11). The 29 principles cover the following:

- Rights to universal enjoyment of human rights, non-discrimination and recognition before the law;

- Rights to human and personal security;

- Economic, social and cultural rights;

- Rights to expression, opinion and association;

- Freedom of movement and asylum;

- Rights of participation in cultural and family life;

- Rights of human right defenders.

In November 2017 a panel of experts published additional principles expanding on the original document, reflecting developments in international human rights law and practice since then. Called 'The Yogyakarta Principles plus 10', it contains 111 'additional state obligations', related to areas such as torture, asylum, privacy, health and the protection of human rights defenders. ${ }^{4}$

\footnotetext{
${ }^{4}$ https://yogyakartaprinciples.org/. See: http://yogyakartaprinciples.org/wpcontent/uploads/2017/11/A5_yogyakartaWEB-2.pdf
} 


\section{Caribbean SIDS}

LGBT people in the Caribbean face significant challenges (Carrillo, 2021: 1): 'Pervasive toxic masculinity, a dominant church which defines rigid gender roles, and staunchly negative public attitudes give the green light for violence, discrimination and harassment of LGBTIQ people, including paving the way for conversion practices'.

\section{LGBT rights}

As noted above, this review only examines rights and legislation affecting LGBT people. Table 1 gives a summary of rights provided for (or not) under law in a number of Caribbean countries. [Note: the final column 'gender identity' refers to the right of people to have their chosen gender recognized in law - to legally express their gender identity, e.g. for a transgender person assigned as male at birth, to be legally accepted as female.]

As Table 1 shows, many Caribbean countries criminalize same-sex sexual activities. In most cases this is a legacy of British colonial rule, reflected in the terms used such as 'buggery' and 'gross indecency'. In countries where same-sex sexual conduct is illegal, punishments vary in severity: in Antigua and Barbuda it is 15 years' imprisonment; in Barbados, life imprisonment; in Grenada, a 10-year prison sentence for males; while in Jamaica, it is two years in prison for physical intimacy between males, and ten years in prison and/or hard labour for anal sex (US DoS, 2020). Same-sex civil unions, marriage and adoption are not permitted across the board: all Caribbean countries ban these. Only Cuba allows LGBT people to serve openly in the military; Grenada and Haiti have no military, but none of the other Caribbean countries allow LGBT people in the military. Cuba is also the only Caribbean country to allow legal change of gender identity.

Human Rights Watch, in a report on the Eastern Caribbean, note that, 'The laws have broad latitude, are vaguely worded, and serve to legitimize discrimination and hostility towards LGBT people in the Eastern Caribbean' (HRW, 2018: 1). This is echoed by Carrillo (2021: 5): 'The existence of these laws continues to perpetuate negative and misleading perceptions of LGBTIQ people as disordered and even criminal, give the green light for harassment, violence, discrimination and conversion practices'.

While the table appears bleak, there has been some progress in the Caribbean in recent years. Belize decriminalized same-sex sexual conduct in 2016, and Trinidad and Tobago in 2018. Carrillo (2021: 5) reports that in recent years the LGBTIQ community and civil society have grown in strength and number: 'Numerous organizations have been formed and obtained legal registration, enabling them to not only more effectively support their communities, but also advocate for legal change'. Cases have been launched by civil society and individuals in St. Vincent \& Grenadines, Jamaica, Barbados and Dominica (Carrillo, 2021: 5). 
Table 1: Provision of LGBT rights in legislation in Caribbean countries

\begin{tabular}{|c|c|c|c|c|c|c|c|}
\hline Country & $\begin{array}{l}\text { Same sex } \\
\text { sexual } \\
\text { relations } \\
\text { decriminalized }\end{array}$ & $\begin{array}{l}\text { Same } \\
\text { sex } \\
\text { civil } \\
\text { union }\end{array}$ & $\begin{array}{l}\text { Same } \\
\text { sex } \\
\text { marriage }\end{array}$ & $\begin{array}{l}\text { Adoption } \\
\text { by same } \\
\text { sex } \\
\text { couples }\end{array}$ & $\begin{array}{l}\text { Open } \\
\text { LGBT } \\
\text { military } \\
\text { service }\end{array}$ & $\begin{array}{l}\text { Anti- } \\
\text { discrimination }\end{array}$ & $\begin{array}{l}\text { Gender } \\
\text { Identity }\end{array}$ \\
\hline $\begin{array}{l}\text { Antigua \& } \\
\text { Barbuda }\end{array}$ & No & No & No & No & No & No & No \\
\hline Bahamas & Yes & No & No & No & Yes & No & No \\
\hline Barbados & No & $\mathrm{No}^{*}$ & No & No & No & Yes & No \\
\hline Belize & Yes & No & No & No & No & Yes & No \\
\hline Cuba & Yes & No & No & No & Yes & Yes & Yes \\
\hline Dominica & No & No & No & No & No & No & No \\
\hline $\begin{array}{l}\text { Dominican } \\
\text { Republic }\end{array}$ & Yes & No & No & No & No & No & No \\
\hline Grenada & $\begin{array}{l}\text { No for males } \\
\text { Yes for } \\
\text { females }\end{array}$ & No & No & No & $\mathrm{N} / \mathrm{A}$ & No & No \\
\hline Guyana & No & No & No & -- & Yes & No & No \\
\hline Haiti & Yes & No & No & No & $\mathrm{N} / \mathrm{A}$ & No & No \\
\hline Jamaica & $\begin{array}{l}\text { No for males } \\
\text { Yes for } \\
\text { females }\end{array}$ & No & No & No & No & No & No \\
\hline $\begin{array}{l}\text { St. Kitts } \\
\text { and Nevis }\end{array}$ & $\begin{array}{l}\text { No for males } \\
\text { Yes for } \\
\text { females }\end{array}$ & No & No & No & No & No & -- \\
\hline St. Lucia & $\begin{array}{l}\text { No for males } \\
\text { Yes for } \\
\text { females }\end{array}$ & No & No & No & $\mathrm{N} / \mathrm{A}$ & No & No \\
\hline $\begin{array}{l}\text { St. Vincent } \\
\& \text { the } \\
\text { Grenadines }\end{array}$ & No & No & No & No & $\mathrm{N} / \mathrm{A}$ & No & No \\
\hline Suriname & Yes & No & No & No & -- & Yes & No \\
\hline $\begin{array}{l}\text { Trinidad } \\
\text { \& Tobago }\end{array}$ & Yes & No & No & No & No & No & No \\
\hline
\end{tabular}

Source: Diverse sources including Carillo (2021), HRW (2017), Wikipedia (2021) and US DoS (2020). 
${ }^{*}$ Foreign (international) same-sex civil unions are recognized for immigration purposes.

\section{Implementation and enforcement}

With regard to implementation and enforcement, the Human Rights Watch report on LGBT people in the Eastern Caribbean, asserts: 'They are rarely enforced by way of criminal prosecutions but all share one common trait: by singling out, in a discriminatory manner, a vulnerable social group they give social and legal sanction for discrimination, violence, stigma, and prejudice against LGBT individuals' (HRW, 2018: 9). US Department of State country human rights reports for 2019 also confirm that punishments for same-sex sexual conduct are not enforced: in the case of Antigua and Barbuda, Barbados and Grenada there were no reports of laws criminalizing same-sex/homosexual sex being enforced, while in Jamaica the government enforced the law criminalizing anal sex only in cases of sexual assault and child molestation (US DoS, 2020).

Conversely, LGBT people in the region do not have confidence seeking protection or justice from law enforcement agencies: 'Many of those interviewed by Human Rights Watch explained that they did not trust the police enough to report incidents of abuse against them. Those that did described negative experiences, including inefficiency, inaction, and antipathy' (HRW, 2018: 3). The US Department of State human rights report for Jamaica in 2019 cites an NGO, referring to cases of discrimination against LGBTI individuals: 'Underreporting continued to be a problem, as many of the persons who made reports were reluctant to go to police because of fear of discrimination or police inaction' (US DoS, 2020).

In its 2019 report on Jamaica, Amnesty International states that the NGO J-FLAG 'continued to receive reports of .... police abuse targeted against LGBTI people'. ${ }^{5}$ Though not confined to the Caribbean, a report by the Human Dignity Trust (HDT) confirms lack of confidence in the police on the part of transgender people. It found (HDT, n.d.: 8):

In multiple studies from the Americas, Africa and Asia, overwhelming majorities of trans and gender diverse people experience harassment, violence and abuse from state officials, and identify them as the main perpetrators of their discrimination. The abuse reported by trans and gender diverse people includes blackmail, extortion, public humiliation, and physical and sexual violence. This occurs both in countries where there are laws that are used to criminalise trans and gender diverse people, and in countries without such criminalising provisions.

\section{Pacific Ocean SIDS}

LGBT people in Pacific SIDS are maltreated and discriminated against in numerous ways (OHCHR, 2015, cited in APF \& UNDP, 2016: 30):

Pacific islanders of all ages who are perceived to be LGBTI suffer from human rights violations ... There have been reports in the region of punitive rape of women perceived to be lesbian. Homophobic ... bullying in schools denies young people safe access to education and often leads to students dropping out of school. A disproportionate number

\footnotetext{
${ }^{5}$ https://www.amnesty.org/en/countries/americas/jamaica/report-jamaica/
} 
of LGBTI youth commit suicide due to physical and psychological abuse. These issues often result in LGBTI people not being able to reach their full potentials with reduced access to health care, education and stable employment keeping them from being integrated members of their societies.

\section{LGBT rights}

Table 2 gives the provisions in law with regard to LGBT rights in Pacific SIDS. As seen, they present a very similar picture to the Caribbean. Only Fiji, Nauru and Vanuatu have fully decriminalized same-sex sexual conduct (i.e. for both males and females); in Cook Islands, Kiribati, Papau New Guinea (PNG), Samoa, Solomon Islands, Tonga and Tuvalu, male homosexual sex is illegal. Punishments range from 5-7 years' imprisonment in Samoa, to up to 10 years in Tonga, 3-14 years in PNG, and 5-14 years' imprisonment in Kiribati (Wikipedia, 2021). Rodrigues (2019: 14) notes that while a number of countries do not make lesbian sex illegal, 'lesbian sex is still not culturally accepted across much of the region and attracts similar stigma to male homosexual sex'.

The Pacific SIDS uniformly do not allow same-sex civil unions or marriage, nor adoption by same-sex couples, nor do they allow LGBT people to openly serve in the military. While a number of countries have provisions prohibiting discrimination on the basis of sexual orientation and gender identity, Rodrigues (2019: 14) asserts that only Fiji has a comprehensive antidiscrimination law - the others tend to prohibit discrimination largely in relation to employment. [Fiji was only the second country in the world to include a constitutional prohibition on discrimination on the grounds of sexual orientation or gender identity and expression - the other country being South Africa (Gerber, 2014)].

Rodrigues (2019: 15) further notes that none have passed legislation in relation to legal gender recognition, though Samoa has decriminalised impersonation of women. 'This is despite a strong historical and cultural tradition of a third gender in many Pacific countries' (Rodrigues, 2019: 15). For example, Samoa has a traditional third gender community called fa'afafine, who are assigned as male or female at birth but embody traits across the gender spectrum. 'Despite their historical acceptance, fa'afafine have no path to legal gender recognition' (Outright International' ${ }^{6}$ ).

\footnotetext{
${ }^{6}$ https://outrightinternational.org/region/samoa
} 
Table 2: Provision of LGBT rights in legislation in Pacific island countries

\begin{tabular}{|c|c|c|c|c|c|c|c|}
\hline Country & $\begin{array}{l}\text { Same sex } \\
\text { sexual } \\
\text { relations } \\
\text { decriminalized }\end{array}$ & $\begin{array}{l}\text { Same } \\
\text { sex } \\
\text { civil } \\
\text { union }\end{array}$ & $\begin{array}{l}\text { Same } \\
\text { sex } \\
\text { marriage }\end{array}$ & $\begin{array}{l}\text { Adoption } \\
\text { by same } \\
\text { sex } \\
\text { couples }\end{array}$ & $\begin{array}{l}\text { Open } \\
\text { LGBT } \\
\text { military } \\
\text { service }\end{array}$ & $\begin{array}{l}\text { Anti- } \\
\text { discrimination }\end{array}$ & $\begin{array}{l}\text { Gender } \\
\text { Identity }\end{array}$ \\
\hline Fiji & Yes & No & No & No & -- & Yes & No \\
\hline Kiribati & $\begin{array}{l}\text { No for males } \\
\text { Yes for } \\
\text { females }\end{array}$ & No & No & No & $\mathrm{N} / \mathrm{A}$ & Yes & No \\
\hline $\begin{array}{l}\text { Marshall } \\
\text { Islands }\end{array}$ & Yes & No & No & No & $N / A$ & Yes & -- \\
\hline Micronesia & Yes & No & No & No & $N / A$ & Yes & -- \\
\hline Nauru & Yes & No & No & No & $N / A$ & No & No \\
\hline Palau & Yes & No & No & No & $\mathrm{N} / \mathrm{A}$ & No & No \\
\hline $\begin{array}{l}\text { Papua } \\
\text { New } \\
\text { Guinea }\end{array}$ & $\begin{array}{l}\text { No for males } \\
\text { Yes for } \\
\text { females }\end{array}$ & No & No & No & No & No & No \\
\hline Samoa & $\begin{array}{l}\text { No for males } \\
\text { Yes for } \\
\text { females }\end{array}$ & No & No & No & $\mathrm{N} / \mathrm{A}$ & Yes & -- \\
\hline $\begin{array}{l}\text { Solomon } \\
\text { Islands }\end{array}$ & No & No & No & No & $N / A$ & No & No \\
\hline $\begin{array}{l}\text { Timor- } \\
\text { Leste }\end{array}$ & Yes & No & No & No & -- & No & -- \\
\hline Tonga & $\begin{array}{l}\text { No for males } \\
\text { Yes for } \\
\text { females }\end{array}$ & No & No & No & No & No & No \\
\hline Tuvalu & $\begin{array}{l}\text { No for males } \\
\text { Yes for } \\
\text { females }\end{array}$ & No & No & No & $\mathrm{N} / \mathrm{A}$ & No & -- \\
\hline Vanuatu & Yes & No & No & No & -- & Yes & No \\
\hline
\end{tabular}

Source: Diverse sources including Rodrigues (2019), Wikipedia (2021) and US DoS (2020). 


\section{Implementation and enforcement}

The US country human rights reports for 2019 uniformly assert that in Kiribati, PNG, Samoa, Tonga and Tuvalu - all with laws criminalizing same-sex sexual conduct - there were no prosecutions/these provisions were not enforced (US DoS, 2020). Gerber (2014) notes that, despite some of the progressive laws in Fiji, LGBTI Fijians still face discrimination, including by the police, for example in 2012, cancelling a permit for the first ever Pride march which had been organized for IDAHOT?

A report by the Asia Pacific Forum and UNDP (2016: 154) highlights the fact that LGBT people in the region are not simply targeted through laws on sexual conduct:

In addition to laws directly criminalising same sex sexual conduct between consenting adults, a range of other laws containing criminal sanctions have been used to target people of diverse sexual orientations and gender identities. These include laws relating to: vagrancy, public nuisance, national security, public morality, obscenity, indecency and public order. The existence of some such laws, or their discriminatory application, breach rights to equality and non-discrimination.

\section{Atlantic-Indian Ocean-South China Sea SIDS}

This grouping has a number of quite geographically dispersed SIDS, including Comoros, Mauritius and the Seychelles in the Indian Ocean off East Africa, Maldives off Sri Lanka and India, and Singapore in South-east Asia.

\section{LGBT rights}

A large number of countries in this group have decriminalized same-sex sexual conduct. However, it is noteworthy that the most developed SID with the largest economy, Singapore, does not allow homosexual sex. This shows that discrimination against LGBT people is not simply a developing country issue. Punishments for same-sex sexual conduct vary: in Maldives it can be up eight years' imprisonment, house arrest, lashings and fines; in Comoros and Mauritius five years' imprisonment (and fines in the former); and in Singapore two years' imprisonment.

These SIDS are uniform in not recognizing same-sex civil unions or marriages, and in not allowing adoption by same-sex couples. With regard to anti-discrimination laws, it is ironic that Mauritius - which bans homosexual sex - has laws banning all anti-gay discrimination.

\section{Implementation and enforcement}

Of the countries in this grouping which criminalize same-sex sexual conduct, Comoros reported no arrests or prosecutions in 2019 and did not actively enforce the law (US DoS, 2020). In Mauritius the statute criminalizing sodomy was reported to have been rarely used against samesex couples unless one of the partners cited sodomy in the context of sexual assault. However, the US DoS 2019 report also noted that: 'LGBTI victims of verbal abuse or violence generally did not file complaints with police for fear of ostracism or, in some cases, fear of reprisal from family members' (US DoS, 2020).

\footnotetext{
7 International Day Against Homophobia and Transphobia.
} 
In the case of Singapore, despite Section 377A of the penal code criminalizing sexual relations among males, this has not been enforced since 2010 and government leaders have stated they do not intend to do so, even though Section 377A will remain part of the country's law 'for some time' (Prime Minister Lee cited in US DoS, 2020). However the US country human rights report points out: 'Its existence, however, intimidates some gay men, particularly those who are victims of sexual assault but who will not report it to the police for fear of being charged with violating Section 377A' (US DoS, 2020).

While laws criminalizing homosexual sex are not enforced, there are other ways in which the government restricts LGBT rights. Human Rights Watch asserted in 2017 that the Singapore Media Development Authority effectively prohibits all positive depictions of LGBT lives on television or radio. Following a number of corporations (including Google, Barclays, Apple and Facebook) sponsoring the annual Pink Dot Festival in support of LGBT rights in 2016, the Ministry of Home Affairs warned multinational companies to stop funding the event, saying such support constituted 'foreign interference' in domestic affairs (HRW, 2017b). The Registrar of Societies, with which all associations of more than ten people must register, has refused to allow any LGBT organization to register as a society on the grounds that 'it is contrary to the public interest to grant legitimacy to the promotion of homosexual activities or viewpoints' (HRW, 2017b). 
Table 3: Provision of LGBT rights in legislation in Atlantic-Indian Ocean-South China Sea countries

\begin{tabular}{|c|c|c|c|c|c|c|c|}
\hline Country & $\begin{array}{l}\text { Same sex } \\
\text { sexual } \\
\text { relations } \\
\text { decriminalized }\end{array}$ & $\begin{array}{l}\text { Same } \\
\text { sex } \\
\text { civil } \\
\text { union }\end{array}$ & $\begin{array}{l}\text { Same } \\
\text { sex } \\
\text { marriage }\end{array}$ & $\begin{array}{l}\text { Adoption } \\
\text { by same } \\
\text { sex } \\
\text { couples }\end{array}$ & $\begin{array}{l}\text { Open } \\
\text { LGBT } \\
\text { military } \\
\text { service }\end{array}$ & $\begin{array}{l}\text { Anti- } \\
\text { discrimination }\end{array}$ & $\begin{array}{l}\text { Gender } \\
\text { Identity }\end{array}$ \\
\hline Bahrain & Yes & No & No & No & No & No & Yes \\
\hline $\begin{array}{l}\text { Cabo } \\
\text { Verde }\end{array}$ & Yes & No & No & No & -- & Yes & -- \\
\hline Comoros & No & No & No & No & No & No & -- \\
\hline $\begin{array}{l}\text { Guinea- } \\
\text { Bissau }\end{array}$ & Yes & No & No & No & -- & No & -- \\
\hline Maldives & No & No & No & No & No & No & No \\
\hline \multirow[t]{2}{*}{ Mauritius } & No for males & No & No & No & No & Yes & -- \\
\hline & $\begin{array}{l}\text { Yes for } \\
\text { females }\end{array}$ & & & & & & \\
\hline $\begin{array}{l}\text { Sao Tome } \\
\text { \& Principe }\end{array}$ & Yes & No & No & No & -- & No & -- \\
\hline Seychelles & Yes & No & No & No & -- & Yes & -- \\
\hline \multirow[t]{2}{*}{ Singapore } & No for males & No & No & No & $\mathrm{No}^{*}$ & No & Yes $^{* *}$ \\
\hline & $\begin{array}{l}\text { Yes for } \\
\text { females }\end{array}$ & & & & & & \\
\hline
\end{tabular}

Source: Diverse sources including Wikipedia (2021) and US DoS (2020).

* LGBT people can serve due to conscription, but are not allowed to go to command school or serve in sensitive units.

** Only after sex change surgery.

\section{Evidence from approaches/programmes to promote LGBT rights}

\section{Importance, challenges and approaches}

It is important to ensure that LGBT people can openly express their sexual orientation and gender identity without being stigmatised, discriminated against, or attacked. The OECD (2019: 38-39) lists three reasons why this should be a policy priority:

- Ethical - sexual orientation and gender identity are integral aspects of our selves. Guaranteeing that LGBT people are not condemned to forced concealment or retaliation when their identity is revealed should constitute an inalienable human right.

- Economic - exclusion of LGBT people impedes economic development through a wide range of channels, such as lower investment in human capital, reduced output and 
productivity, and public spending on social and health services that might be better spent elsewhere.

- Social - LGBT inclusion is viewed as conducive to the emergence of less restrictive gender norms that improve gender equality broadly speaking and, hence, expand social and economic roles, especially for women. Acceptance of homosexuality is strongly correlated with support for gender equality worldwide.

However, there are several challenges involved in trying to address LGBT issues in development assistance and programming:

- Issues related to sexual orientation and gender identity are considered highly controversial and difficult to address with partner governments (Kampf, 2015: 13). This is especially true in the Caribbean (Holness, 2013).

- LGBT issues are seen as affecting only a relatively small percentage of the population (Kampf, 2015: 13).

- Even in donor countries, decriminalization and social acceptance of LGBTI has been a recent phenomenon: 'Western development cooperation practitioners may not be significantly more tolerant of LGBTI than are their counterparts in the countries they work in' (Kampf, 2015: 13).

International actors and development agencies can promote LGBT rights and inclusion in SIDS (and other developing countries) in a number of ways:

- Advocacy to promote LGBT rights, including through diplomacy and/or aid conditionality, with arguments including the economic costs of discrimination against LGBT people on a country's economy (Badgett, 2014)

- Programmes to address HIV/AIDS and promote sexual and reproductive health care

- Mainstreaming LGBT issues/concerns into development programmes (inclusive development)

- Engagement with civil society/LGBT groups to raise their voice, build their capacity and make them more effective in influencing decision-makers, their communities and society

- Research on LGBT issues to provide an evidence base for advocacy and programming.

The OECD stress the need to make LGBT individuals and the discriminatory behaviour they face visible in national statistics. 'Collecting information on sexual orientation and gender identity in censuses as well as national labour force, health and victimisation surveys is critical to create awareness' (OECD, 2019: 40). They argue that greater publicity of discriminatory behaviour can bring about meaningful change (OCED, 2019: 39). The OECD also place emphasis on legislation: 'One cannot expect to improve the situation of sexual and gender minorities if, to begin with, the law does not protect them against discrimination and abuses' (OECD, 2019: 4142). But they add that laws must be enforced: 'enacting anti-discrimination and equality laws is not sufficient per se to protect sexual and gender minorities. These laws must also be fully enforced, meaning that reporting, recording and sanctioning of anti-LGBT offences at home, at work, on the street, online, etc. should become more systematic' (OECD, 2019: 42).

The remainder of this section looks at different examples of approaches to promote LGBT rights and inclusion in SIDS (and other countries in the Asia-Pacific region). 


\section{Advocacy through regional bodies in the Caribbean}

Holness (2013) contrasts the effectiveness (or lack of it) of global LGBT rights advocacy (rooted in fundamental human rights principles such as the Universal Declaration on Human Rights) and international direct advocacy to promote LGBTI rights in the Caribbean, with use of regional bodies. She argues that global scale advocacy on LGBTI rights comes up short because the global rights dialogue is 'dominated by the few elite voices of Western Europe and the United States. As a result, global human rights bodies enjoy limited buy-in from the developing world' (Holness, 2013: 938). On international direct advocacy targeting LGBTI hostile actors, she identifies two reasons for why this often fails (Holness, 2013: 935-6):

- First, direct advocacy can be, and often is, readily rejected as cultural imperialism. Consequently, the LGBTI norms being advanced through international direct advocacy are categorically rejected as foreign norms, alien to the local population. Many LGBTIhostile communities consider LGBTI rights advocacy to be a form of cultural imperialism.

- The second drawback of direct advocacy is its potential to compromise the efforts of local LGBTI advocates and invite retaliation against local LGBTI communities. Direct advocacy efforts from the international community targeting local Caribbean populations have a strong potential to muddy the waters by branding the LGBTI movement as a foreign agenda.

She gives the example of Jamaica and Red Stripe to illustrate the second of these (Holness, 2013: 936-7). In 2009 a US-based LGBTI lobby group launched a campaign to boycott Jamaican products, including Red Stripe beer, to pressure the government to show greater respect for sexual minorities. J-FLAG ${ }^{8}$, the leading Jamaican NGO working for LGBT rights, criticized the boycott as ineffective and ignorant of the local dynamic. They noted that Red Stripe had actually supported the LGBTI community. However, the US lobby ignored J-FLAG with the result that not only was the boycott ineffective but it actually reversed the progress made by local LGBTI advocacy efforts.

LGBTI advocates in Belize suffered a similar blow. Just as their advocacy efforts to decriminalize homosexual conduct were making progress in 2012, London-based activists launched a campaign targeting Belize and other states in which same sex conduct was criminalized. This enabled local opponents to decriminalization to launch a vociferous counter campaign, arguing that the Belizean LGBTI rights campaign was a foreign import rather than a grassroots effort this stunted the latter.

Holness (2013: 939-49) argues that regional bodies are more suitable forums for advancing LGBTI rights in the Caribbean for at least four reasons:

- Collective action obstacles are substantially reduced with the lower number of state participants - since regional bodies have fewer members than global bodies such as the UN: there are fewer interests that must be reconciled to reach agreement; it is harder for individual members not to participate (to 'free ride'); and there are lower costs, and greater rewards for members compared to those in larger groups.

\footnotetext{
8 Jamaica Forum for Lesbians, All-Sexuals and Gays (J-FLAG).
} 
- Regional similarities make it easier to negotiate common ground and reach human rights agreements - similarities in ethnic, cultural and religious beliefs, as well as shared histories and socio-political resemblances bolster the capacity of regional neighbours to reach agreements, especially regarding culturally charged matters such as LGBTI rights.

- Regional bodies enjoy more equitable power dynamics, which promote collective bargaining - in global/larger groupings, the vast power differential between nations undermines human rights advocacy, one, because less powerful developing nations have little or no ability to enforce compliance, and two, developing nations do not have the same level of participation in international norm-development process due to structural biases. These two factors undermine whatever human rights advances global bodies can achieve.

- Regional bodies give the domestic LGBTI community a greater voice in the movement toward LGBTI equality - with fewer members, regional bodies allow more participants for each state meaning there is greater space for LGBTI people themselves to play a role.

In the Caribbean, Holness identifies the Inter-American Commission on Human Rights and the Caribbean Court of Justice as appropriate regional bodies for LGBTI rights advocacy.

Writing specifically about Jamaica, which they describe as one of the most homophobic countries in the world, Blake and Dayle (2013: 472-3) echo Holness in cautioning about international advocacy: "Activism should not smack of a "rescue" mission by erstwhile colonial masters or appear to be top-down gestures from rich industrialised nations to a backward third world country'. Rather they call for 'genuine partnerships that empower local activists' and stress the need for 'the lobbying resources, political heft and broad-based mobilisation that comes not just through local actors, but with international partners' (Blake \& Dayle, 2013: 473).

\section{Addressing research gaps: 'Being LGBTI in Asia and the Pacific'" and 'Being LGBTI in the Caribbean" ${ }^{10}$ projects}

Being LGBTI in Asia and the Pacific is a regional programme which seeks to fill the large research gaps that currently exist on the stigma, discrimination, violence and human rights violations experienced by LGBT people. The aim is to equip duty bearers with the strategic information needed to address the issues faced by LGBT people, and to ensure they have equal access to justice and public services such as health and education. Integral to promoting inclusion by LGBT people is increased participation of LGBT people in policy development.

Being LGBT in Asia and the Pacific is a collaboration between governments, civil society groups, regional institutions and other stakeholders. It is supported by several international development partners, notably UNDP, USAID and Australia's Department for Foreign Affairs and Trade (DFAT). As well as individual country reports on the situation of LGBT people, and reports on specific themes such as employment discrimination and legal rights, the programme has produced manuals on promoting LGBT inclusion for various stakeholders, notably parliamentarians and national human rights institutions.

\footnotetext{
${ }_{9}^{9}$ https://www.asia-pacific.undp.org/content/rbap/en/home/programmes-and-initiatives/being-lgbt-in-asia.html

${ }^{10} \mathrm{https}: / /$ www.bb.undp.org/content/barbados/en/home/projects/BLIC.html
} 
The Being LGBTI in the Caribbean programme is based on the Asia-Pacific one. It focuses on a number of countries in the Caribbean: Barbados, St. Lucia and Grenada, the Dominican Republic, Haiti and Jamaica, but also has regional activities and dialogues. As with the Being LGBT programme in the Asia-Pacific, there is a strong emphasis on research and evidence and knowledge dissemination. This supports 'meaningful engagement' with national governments, as well as capacity building of LGBT community groups. The programme is funded in large part by USAID, with implementation led by UNDP. A September 2018 update of the programme reports engagement with government agencies for national dialogues as well as considerable work on capacity assessment and training of civil society organizations (USAID \& UNDP, 2018).

\section{UNDP engagement in the Pacific}

The United Nations Development Programme is working across the Pacific SIDS to promote LGBT rights, using a range of approaches (Rodrigues, 2019: 25):

- Sensitising parliamentarians - Since the early 2000s, UNDP has supported parliamentary strengthening activities across the region, through both national and regional projects and activities. UNDP organises capacity-building seminars for MPs, often in collaboration with subject matter experts and supports post-election inductions for MPs to build awareness around subject-specific law reform issues (e.g. gender equality, climate change, HIV, human rights).

- $\quad$ HIV/AIDS programming - UNDP also works closely with UNAIDS and other partners. The multi-country Western Pacific integrated HIV/TB programme supported by the Global Fund aims to strengthen control of HIV and tuberculosis (TB) in 11 Pacific island countries: Cook Islands, Federated States of Micronesia (FSM), Kiribati, Nauru, Niue, Palau, Republic of Marshall Islands (RMI), Samoa, Tonga, Tuvalu and Vanuatu. The programme works with key populations (female sex workers, men who have sex with men (MSM), transgender people) who have limited access to prevention and testing services due to stigma, discrimination and other social barriers.

- Legislative reform - UNDP also supports law reform and has organised a national consultation on SOGIESC+ issues with the Asia Pacific Forum (APF) and Fijian partners in 2018, as well as commissioning law reform research in Tonga. This work is being implemented as part of the Being LGBTI in Asia and the Pacific project (see above).

- Access to health services - UNDP and UNAIDS also have strong partnerships with national Pacific ministries of health, who work to decriminalise homosexuality and promote safe homosexual sex through access to health services for marginalised groups.

\section{Successful approaches in the Asia-Pacific region}

A UNDP report on advancing inclusion of LGBTI people in Asia and the Pacific (UNDP, 2015) highlights progress in a number of areas, e.g. decriminalization of same-sex consensual sex, legal recognition of 'third gender' (transgender) people, anti-discrimination legislation and pride parades. It attributes this progress to three factors (UNDP, 2015: 5):

- Firstly, the response to HIV has been used as an entry point to advocacy for LGBTI rights. It has led to policies, statements and resolutions that address SOGIE, and the mobilization of men who have sex with men (MSM) and transgender women has built advocacy skills, 
networks of influence and social capital within these communities. It has also increased visibility of MSM and transgender women, led to partnerships between communities and government, and brought greater attention to the legal and human rights contexts.

- Secondly, LGBTI visibility is increasing in general in Asia and the Pacific with community mobilization, and pride marches and festivals, assisted by the growth of social media. LGBTI people are more visible in politics, media and the private sector. All this contributes to a more supportive environment for LGBTI people across the region.

- Landmark developments in law and policy reform are creating more positive social environments for LGBTI people. These include the decriminalization of homosexual conduct, and the enactment of legal protections from discrimination relating to sexual orientation and gender identity or gender expression in some countries. The past five years have seen a wave of progressive judicial decisions on the rights of transgender people from Hong Kong SAR, India, Malaysia, Nepal and Pakistan. In recent years, LGBTI issues have also been considered for the first time by many government agencies and national parliaments. In another positive legal development, national human rights institutions (NHRIs) of Asia and the Pacific have recognized that their responsibilities extend to protection and promotion of SOGIE-related human rights.

\section{Recommendations}

This review also found a number of papers/reports with recommendations for international development actors (donors) when trying to promote LGBT rights and inclusion. These were not aimed at specific countries or regions, but rather were generic.

\section{Sustainable Development Goals and inclusive development}

The Sustainable Development Goals (SDGs) were adopted by the UN in August 2015. While not explicitly mentioning LGBT people, the SDGs are based on the principle of 'leave no one behind'. The UN issued a report Leave no one behind: Gender, sexuality and the SDGs (Mills, 2015) as part of a collective 'push' to provide empirical evidence for development actors to use the language of the SDGs as a tool to address social exclusion of LGBT groups in development programming. The findings in the report were based on a comprehensive review of empirical literature on sexuality, gender and development, as well as primary research ${ }^{11}$. It argues that without deliberate action by development actors at international and national level, "billions of people will be excluded from the benefits of international development because of their sexual orientation and gender identity' (Mills, 2015: 4).

The report recommends that, to promote inclusive development, international development actors can (Mills, 2015: 6):

- Consult with local LGBTI groups in countries of operation. Listen to and work according to their needs and strategies.

${ }^{11}$ Conducted on the Sexuality, Poverty and Law Programme (SPLP). 
- Generate two-way processes of capacity building so local knowledge can bolster international action, and so that international knowledge can support local action using the SDG framework to lobby for change.

- Lobby for greater SOGIE inclusion in international development frameworks, using SDG commitments as a primary justification. In doing so, emphasise that SOGIE rights are not 'special rights': all human beings are entitled to be treated equally without discrimination.

- Establish programmes and projects that explicitly integrate SOGIE issues across all spheres of development. The 'leave no one behind' discourse and SDG framework can offer primary justification.

- Highlight success stories where SOGIE individuals and groups have been integrated into programmes with an SDG justification.

- Sensitise delivery partners and staff to 'leave no one behind' principles and how they should apply to LGBTI and other marginalised groups.

- Consider SOGIE policy when choosing delivery partners. Integrate this awareness into procurement processes.

\section{Role of state donors in promoting LGBTI rights in development cooperation}

Also released in 2015, a report by the German Institute for Human Rights looks at how state donors can further LGBTI rights in development cooperation. Drawing primarily on studies in Africa, it makes the following recommendations (Kampf, 2015: 9-11):

- Do support SOGI rights - SOGI human rights are an integral part of international human rights law. If donors take their human rights policies seriously they should be promoting SOGI human rights through development cooperation.

- Talk about SOGl rights as human rights - SOGI human rights can and should be raised in political dialogue just as violations against other groups, such as women or religious minorities, should be. Talks should be framed within a larger human rights framework, focusing on acknowledged rights to non-discrimination and privacy.

- Address value issues, but smartly - In order for human rights to attain relevance in local discourse, they need to be linked to the values that are their functional equivalents in the set of values shared by people in that society, or in other words, translated into the local discourse. The best way for donors to promote LGBTI rights in national discussions is from "the backseat". Thus donors need to let local actors steer the course, let them give voice to SOGI demands and support them in building capacity at the individual and organisational level.

- Coordinate when needed - but variation is important - As a general rule, donors should coordinate. Coordination is effective when it is used to promote a common position. When it comes to funding, donor coordination may not always bring about the desired results. An informed, but diversified approach to civil society support may be the best way to maintain or even further different approaches of CSOs and movements and avoid blueprints.

- Review criteria for sustainability and ownership when funding contentious human rights issues - Sustainability is usually a goal of state development cooperation. However, CSOs that work on issues their governments do not approve of, can struggle to attract funding for programmes previously supported by donors. Such organisations will probably remain aid 
dependent for some time to come - thus donors should review and adapt their sustainability criteria in order to enable LGBTI CSOs to play their crucial part in effecting change.

- Understand visibility - and have emergency procedures ready - Visibility - understood as public discussion about sexual orientation and gender identity - is a necessary element of promoting respect and human rights for LGBTI. Neither activists nor donors are able to control the process or the outcome of public debates. As public discussion can also trigger violence and backlash against LGBTI, donors should be prepared and have safeguards in place, such as local shelters, regional travel funds or non-bureaucratic asylum procedures.

- Work with traditional and religious leaders - In order to create ownership, development cooperation needs to connect to local structures and procedures. Development cooperation should be conscious of and take advantage of the fact that rather than being static or monolithic, tradition and religion are ever evolving. Change agents exist in both communities and can and should be approached as to which support they consider useful.

- Aid cuts - if you think they are really necessary, consult LGBTI in any case - When considering aid cuts, donors and diplomats should consult with activists beforehand as to how they assess the possible impacts. For this to happen, communication channels need to be established before any such incident arises. Any decision about aid cuts should be based on an analysis of the full range of human rights - as singling out LGBTI might contribute to their stigmatisation.

- Practice what you preach - "Walk the talk" implies sensitising agency staff both with regard to both their professional work and the working environment. Staff needs to be sensitised about working in contexts where LGBT are subject to stigmatisation and/or criminalisation, and taught ways to address this. This sensitisation should be accompanied and reinforced by an internal staff policy that explicitly addresses discrimination based on sexual orientation or gender identity. And make diversity a criterion for hiring - and LGBTI a diversity criterion.

- Close gaps: lesbians - trans - inter - For programmes to be really inclusive of the full range of L-G-B-T-I, donors need to be clear about whom they actually reach. Existing approaches such as the public health approach can and should be extended to be inclusive of lesbians due to their social situation, which renders them more exposed to HIV/AIDS. Programmes which are intended to empower women should be expanded to consider the specific situation of lesbians, for example through women's empowerment programmes or programmes on gender-based violence.

- Support necessary research and learning - Studies about prevalence and life situations of LGBTI, which could inform development programming and implementation, are still lacking for many contexts. The same applies for processes of change - some narratives of activism and how it contributes to social and legal change do exist, but they are often not in a publicly accessible and easily digestible format, while other processes haven't been documented yet.

\section{References}

APF \& UNDP (2016). Promoting and protecting human rights in relation to sexual orientation, gender identity and sex characteristics: A manual for national human rights institutions. Asia Pacific Forum of National Human Rights Institutions and United Nations Development Programme. https://www.asia- 
pacific.undp.org/content/rbap/en/home/library/democratic_governance/hiv_aids/promoting-andprotecting-human-rights-in-relation-to-sexual-orie.html

Badgett, M. (2014). 'The Economic Case for Supporting LGBT Rights'. The Atlantic, 29 November 2014. https://www.theatlantic.com/business/archive/2014/11/the-economic-case-forsupporting-lgbt-rights/383131/

Blake, C. \& Dayle, P. (2013). 'Beyond cross-cultural sensitivities: international human rights advocacy and sexuality in Jamaica', in Lennox, C. \& Waites, M. (eds.), Human Rights, Sexual Orientation and Gender Identity in The Commonwealth: Struggles for Decriminalisation and Change. University of London. https://sasspace.sas.ac.uk/4824/2/17BlakeDoyle_HumanRightsSexualityJamaica.pdf

Carrillo, K. (2021). Conversion Practices: The Caribbean Story. Outright Action International. https://outrightinternational.org/sites/default/files/CaribbeanReport2021_26Jan.pdf

Gerber, P. (2014). 'Why the Pacific islands are no gay paradise'. Monash University. https://www.monash.edu/news/opinions/why-the-pacific-islands-are-no-gay-paradise

Holness, T. (2013). 'Lesbian, Gay, Bisexual, Trans and Intersex Rights in the Caribbean: Using Regional Bodies to Advance Culturally Charged Human Rights'. Brooklyn Journal of International Law, Vol. 38, Issue 3.

https://brooklynworks.brooklaw.edu/cgi/viewcontent.cgi?article=1045\&context=bjil

Human Dignity Trust (n.d.). Injustice Exposed: The criminalisation of transgender people and its impact. https://www.humandignitytrust.org/wp-content/uploads/resources/Injustice-Exposed-thecriminsalisation-of-trans-people.pdf

HRW (2017). "I have to leave to be me." Discriminatory laws against LGBT people in the Eastern Caribbean. Human Rights Watch.

https://www.hrw.org/sites/default/files/report_pdf/easterncaribbean0318_web_0.pdf

HRW (2017b). Human Rights Watch Country Profiles: Sexual Orientation and Gender Identity. Human Rights Watch, 23 June 2017. https://www.hrw.org/news/2017/06/23/human-rights-watchcountry-profiles-sexual-orientation-and-gender-identity

Kampf, A. (2015). 'Just head-banging won't work': How state donors can further LGBT rights in development cooperation and what LGBTI think about it. German Institute for Human Rights. https://www.institut-fuer-

menschenrechte.de/fileadmin/user_upload/Publikationen/Studie/DIMR_Study_How_state_donor s_can_further_human_rights_of_LGBTI_in_development_cooperation_and_what_LGBTI_think_ about_it.pdf

Mills, E. (2015). 'Leave no one behind': Gender, sexuality and the sustainable development goals. Institute of Development Studies.

https://opendocs.ids.ac.uk/opendocs/bitstream/handle/20.500.12413/7104/ER154_LeaveNoOne BehindGenderSexualityandtheSDGs. pdf? sequence $=8$

OECD (2019). 'The LGBT challenge: How to better include sexual and gender minorities?', in Society at a Glance 2019: OECD Social Indicators. Organization for Economic Cooperation and 
Development. https://www.oecd-ilibrary.org/docserver/c64c3d3f-

en. pdf?expires $=1612870387 \& i d=i d \& a c c n a m e=$ guest\&checksum $=45 B C F C D 0853368 B 8 B 7 A B F 34$ D02DB07E7

Rodrigues, C. (2019). A Fairer Future: Law reform and advocacy opportunities for women and PIGSOGIESC+ rights in the Commonwealth Pacific. The Royal Commonwealth Society. https://pgaction.org/pdf/Opportunities_for_women_and_LGBTI_rights_Pacific.pdf

Stonewall International (n.d.). The Sustainable Development Goals and LGBT inclusion. https://www.stonewall.org.uk/system/files/sdg-guide.pdf

UN (2016). Living Free and Equal: What states are doing to tackle violence and discrimination against lesbian, gay, bisexual, transgender and bisexual people. United Nations.

https://www.ohchr.org/Documents/Publications/LivingFreeAndEqual.pdf

UNDP (2015). Leave no one behind: Advancing social, economic, cultural and political inclusion of LGBTI people in Asia and the Pacific. Summary. United Nations Development Programme. https://www.asia-

pacific.undp.org/content/rbap/en/home/library/democratic_governance/hiv_aids/leave-no-onebehind--advancing-social--economic--cultural-and-po.html

USAID \& UNDP (2018). Being LGBT in the Caribbean: Project Update - September 2018. United States Agency for International Development (USAID) and United Nations Development Programme (UNDP).

https://www.bb.undp.org/content/barbados/en/home/library/democratic_governance/being-lgbtiin-the-caribbean---project-update---september-2018.html

US DoS (2020). 2019 Country Reports on Human Rights Practices. United States Department of State. https://www.state.gov/reports/2019-country-reports-on-human-rights-practices/

Wikipedia (2021). 'LGBT rights by country or territory'.

https://en.wikipedia.org/wiki/LGBT_rights_by_country_or_territory

\section{Acknowledgements}

We thank the following experts who voluntarily provided suggestions for relevant literature or other advice to the author to support the preparation of this report. The content of the report does not necessarily reflect the opinions of any of the experts consulted.

- Stephen Brown, University of Ottawa

- Jonathon Fisher, University of Birmingham

- Ellie Gore, University of Sheffield

\section{Key websites}

- Human Dignity Trust: www.humandignitytrust.org

- Kaleidoscope Trust: www.kaleidoscopetrust.com 


\section{Suggested citation}

Idris, I. (2021). LGBT rights and inclusion in Small Island Developing States (SIDS). K4D Helpdesk Report 970. Brighton, UK: Institute of Development Studies. DOI: 10.19088/K4D.2021.067

\section{About this report}

This report is based on six days of desk-based research. The K4D research helpdesk provides rapid syntheses of a selection of recent relevant literature and international expert thinking in response to specific questions relating to international development. For any enquiries, contact helpdesk@k4d.info.

K4D services are provided by a consortium of leading organisations working in international development, led by the Institute of Development Studies (IDS), with Education Development Trust, Itad, University of Leeds Nuffield Centre for International Health and Development, Liverpool School of Tropical Medicine (LSTM), University of Birmingham International Development Department (IDD) and the University of Manchester Humanitarian and Conflict Response Institute (HCRI).

This report was prepared for the UK Government's Foreign, Commonwealth and Development Office ( $F C D O)$ and its partners in support of pro-poor programmes. Except where otherwise stated, it is licensed for non-commercial purposes under the terms of the Open Government Licence v3.0. K4D cannot be held responsible for errors, omissions or any consequences arising from the use of information contained in this report. Any views and opinions expressed do not necessarily reflect those of FCDO, K4D or any other contributing organisation.

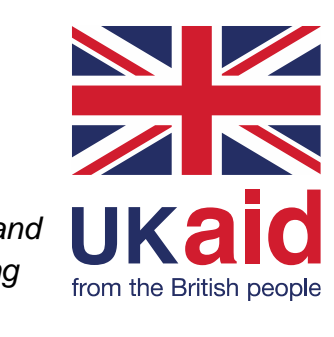

(c) Crown copyright 2021. 